DOI: https://doi.org/10.32839/2304-5809/2020-12-88-65

УДК 811.111-26

Федоренко С.В., Валькова А.О.

Національний технічний університет України

«Київський політехнічний інститут імені Ігоря Сікорського»

\title{
ЛІНГВОКУЛЬТУРНІ ОСОБЛИВОСТІ ПЕРЕКЛАДУ СУЧАСНИХ АНГЛОМОВНИХ ДОКУМЕНТАЛЬНИХ ФІЛЬМІВ
}

\begin{abstract}
Анотація. В даній статті розглядаються проблеми, які виникають в процесі перекладу сучасних англомовних документальних фільмів. Вивчено поняття «кінотекст», визначено, що переклад кіносценаріїв відноситься до художнього перекладу та в той же час має свої унікальні особливості. Досліджено англомовний документальний кінотекст як об'єкт лінгвістичного дослідження та розглянули методи трансляції подій в англомовному документальному кінотексті. Також, проаналізовано лінгвокультурні особливості перекладу сучасних англомовних документальних фрільмів. Ми дослідили лінгвокультурний потенціал сучасних англомовних документальних фрільмів, їх значення, особливості, жанрово-стилістичну специфріку та розгляд науковцями в парадигмі мультимодальності. З'ясовано лінгвокультурну специфіку перекладу мови англомовних документальних кінотекстів. Виявили лінгвокультурний аспект перекладу англомовних документальних кіно текстів та специфіку перекладу документальних фільмів, зокрема, із субтитрами. Було проаналізовано два документальні фільми: «Земляни» та «Пластиковий океан», охарактеризовано переклад, підкреслення складнощів під час перекладу фрільмів такого типу в зв'язку 3 залежністю від часового проміжку, який віддається на оригінальний текст. Найважливішим є обрати такі перекладацькі трансформації, за допомогою яких переклад не буде ані сильно поспішати, ані відставати. У обох фрільмах цей баланс було дуже добре продемонстровано.
\end{abstract}

Ключові слова: кінотекст, документальний кінотекст, аспекти перекладу, лінгвокультурний аспект, трансляція подій.

Fedorenko Svitlana, Valkova Anzhelika National Technical University of Ukraine «Igor Sikorsky Kyiv Polytechnic Institute»

\section{LINGUO-CULTURAL FEATURES OF TRANSLATION OF MODERN ENGLISH-LANGUAGE DOCUMENTARIES}

Summary. The problems that arise in the process of translating modern English documentaries were investigated in this article. Nowadays, humankind is faced with new global problems, such as global warming, the causes and consequences of which are revealed in documentaries. Because English is an international language and more widely spoken, many of these films are made in English. Some of the phenomena presented in documentaries are globally known, others are specific to a particular culture, country, or historical epoch. That is why during translating films, the translator encounters not only the problem of translating complex terms, but also adaptation in the language of the recipients in case of cultural differences. Especially in today's world, we are receiving more and more information about how negative human activities affect the environment. This gives rise to the relevance of documentaries. The important part is also the time, making it more difficult for translators to complete the translation. If the phenomenon is common for the culture of the original language, but not for the language of the recipient, the translator must very briefly reproduce this meaning. Compared to ordinary texts, the problem arises during documentary film translation since the original text and the translation are given the same period of time. Documentary film translation is an important way of knowledge transfer and intercultural communication. It requires the use of translation strategies that take into account the specifics of the language of English-language film text and adaptive methods. Documentaries differ from entertaining films in that they show our life as it is or was and help us make the right choice by changing our attitude towards certain spheres of life. Cinema plays a leading role in mass communication, and the documentary genre is an integral part of cinema, although it is not the first in popularity. Foreign film production is more popular on the Ukrainian market, so correct translation is one of the main factors in the popularity of foreign films in Ukraine.The translation of documentaries covers two or more languages, so the problem of correct language transmission for the accurate perception of information by the viewer comes to the fore. Therefore, the main role is played by the choice of the appropriate translation strategy, which at the same time preserves the originality and removes possible misunderstandings caused by cultural differences.

Keywords: film text, documentary film text, aspects of translation, linguacultural aspect, broadcast of event.

$\Pi$ остановка проблеми. Сьогодні людство затикаеться 3 новими глобальними проблемами, як наприклад, глобальне потепління, про причини і наслідки яких розкриваються у документальних фільмах. Деякі явища, описані у документальних фрільмах є глобально-відомими, інші - специфічними для певної культури, країни, або історичної епохи. Саме тому під час перекладу фільмів, перекладач зустрічається не тільки з проблемою перекладу складних термінів, а й адаптацією у мові реципієнтів при культурній розбіжності. Порівнюючи з звичайними текстами, проблема виникає під час документального кіноперекладу через те, що для оригіналу і перекладу віддається однаковий проміжок часу. Документальний кінопереклад є важливим способом передачі знань та міжкультурної комунікації. Він вимагає застосування перекладацьких стратегій, 
що враховують особливості мови англомовного кінотексту та адаптивні методи.

Кінематографр відіграє провідну роль у масовій комунікації, а жанр документального фрільму $\epsilon$ невід'ємною частиною кінематографру, хоча і посідає в ньому не перше місце за популярністю. На українському ринку більш популярна зарубіжна кінопродукція, тому коректний переклад $є$ одним з головних фракторів популярності іншомовних картин в Україні.

Аналіз останніх досліджень і публікацій. Кінопереклад в Україні активно розвивається. Найбільше основи кіноперекладу освітили такі вчені як А. Г. Гудманян, В. Є. Горшкова, М. С. Снеткова, Г. Г. Слишкін. Та, не зважаючи на вклад вищезгаданих фрахівців, серед мовознавчих робіт немає такої праці, яка детально досліджує та розкриває саме документальне кіно, особливості його мови та перекладу.

Виділення невирішених раніше частин загальної проблеми. Переклад документальних фрільмів у минулому становив більшою частиною лише матеріали, які відносяться до певного історичного періоду. Сучасні документальні фрільми відображають глобальні питання, які $є$ дуже важливими на даному етапі і відіграють велику роль у подальшому існуванні людства. Наразі такі фрільми є досить новими, адже людство усвідомило ці проблеми нещодавно. Дана тема була обрана, адже дослідження щодо лінгвокультурних особливостей перекладу сучасних англомовних фрільмів у вітчизняній науці відсутні.

Формулювання цілей статті. Мета роботи полягає у вивченні, узагальненні та дослідженні специфіки лінгвокультурних особливостей перекладу англомовного документального кінотексту українською мовою.

Матеріалом дослідження $€ 250$ англійських висловлювань 3 документального фрільму «Земляни» та їх переклад на українську мову. Для аналізу було обрано два документальні фрільм «Земляни» 2005 року тривалістю 95 хвилин та «Пластиковий океан» 2016 року тривалістю 100 хвилин.

Виклад основного матеріалу дослідження. Дослідження документального кінотексту як частини кінодискурсу має важливе значення, оскільки сучасний кінематографр є потужним інструментом фрормування масової свідомості та впливу. Відтак, когнітивна природа документального кінотексту обумовлюе необхідність якісного перекладу оригінальних кінокартин 3 метою адекватного відтворення вихідних ідей та орормування цінностей.

Текст досліджують в якості лінгвовізуального феномену з гетерогенною природою, в якому вербальні параметри мають лінгвальну природу, а просодичні параметри виражаються за допомогою нелінгвальних знаків. Саме тому кінотекст вивчається як особлива реалізація відеовербального типу текстів за допомогою співставлення двох головних елементів - вербальної та візуальної складових. Не дивлячись на мультимодальний характер, для кінотексту, також і документальному кінотексту, притаманні універсальні текстові категорії: щілісність, зв’язність, модальність, системність, інформативність, наративність, інтертекстуальність, прагматична направленість.
Переклад фрілму завжди нерозривно пов'язаний 3 певними труднощами не тільки лінгвістичного, а й технічного характеру, що безпосередньо впливає на ступінь еквівалентності та адекватності перекладу оригіналу, а також його технічного втілення на екрані (наприклад, синхронність артикулящії акторів і реплік дублерів).

За класифікацією М. Берді, виділяють 5 основних видів кіноперекладу:

- Синхронний переклад фрільму. В цьому випадку синхроніст переводить фільм без опори на монтажні листи. Іноді він змушений переводити фрільм без попереднього перегляду, намагаючись якомога точніше передати його зміст.

Цей вид перекладу використовувався на міжнародних кінофрестивалях. На сьогодні цей вид перекладу фільмів практично себе вичерпав, тому що всі фольми на міжнародних кінозаходах в обов'язковому порядку субтитруються. Однак говорити, що синхронний переклад фрільмів припинив своє існування, поки передчасно.

- Озвучування фрільму одним актором або самим перекладачем. При цьому зберігається оригінальний звукоряд, що дає можливість глядачеві ощінити емощійний настрій фрільму, а також розмежувати репліки різних героїв.

Це свого роду псевдодубляж, коли в студійних умовах на злегка приглушеним іноземну мову накладається переклад в акторському виконанні. В окремих випадках при випуску фільмів на DVD закадровий переклад робиться на один голос. I робить його, як правило, сам перекладач. При цьому повинно чітко чути голоси акторів.

- Озвучування фрільму двома акторами - чоловіком і жінкою при збереженні оригінального звукоряду.

- Повний дубляж фрільму. Весь фрільм озвучуеться цілим штатом акторів. В цьому випадку відбувається значна компресія матеріалу через необхідність збігу артикуляції акторів з перекладом їх реплік.

Техніка повнощінного і якісного дубляжу коштує дуже дорого. Більш популярним став ліпсінг - дещо спрощений телевізійний дубляж іноземних серіалів, - де укладання тексту під артикуляцію здійснюеться тільки на початку і в кінці фррази.

- Використання титрів при повному збереженні вихідного звукоряду. Мова персонажів відтворюеться у вигляді тексту мовою перекладу в нижній частині екрана. Фільми з субтитрами демонструються на міжнародних кінофестивалях, випускаються в прокат на цифрових носіях 3 перекладом на кілька мов одночасно, а також використовуються в освітніх цілях.

Виділяються три стратегії перекладу назв фрільмів:

1. Прямий переклад англомовних назв фрільмів на українську мову.

2. Трансдормація назви.

Субтитрування фрільмів - один з головних способів перекладу документальних фрільмів, тому важливо знати його позитивні і негативні сторони. Основні переваги даного виду перекладу:

1. Переклад за допомогою субтитрів дозволяє зберегти художню цінність фрільму, дає можливість ощінити майстерність акторів, зберігає їх справжній голос, інтонації в той час як при ду- 
бляжі багато з цих складових губляться як в силу технічних причин, так і в силу недостатньої кваліфрікації акторів, які озвучують переклад. Саме тому на всіх великих кінофестивалях фільми демонструються мовою оригіналу з субтитрами.

2. Даний вид перекладу не спотворюе мову оригіналу і дозволяе глядачеві, котрий володіє базовими мовними знаннями, самому стежити за вмістом діалогів.

3. Переклад за допомогою субтитрів технічно менш складний у виконанні, вимагає участі меншої кількості людей, а, отже, комерційно більш вигідний. Переклад за допомогою субтитрів з'являеться в іноземному прокаті набагато раніше, ніж дубльована версія (не рахуючи «піратських» копій).

4. Переклад кінофрільмів за допомогою субтитрів несе в собі освітню цінність. Використання фрільмів 3 субтитрами допомагае вивчають мову вдосконалювати свої знання, розуміти структуру живої мови, зіставляти мова оригіналу і мову перекладу. Одним з видимих недоліків розглянутого виду перекладу $е$, на наш погляд, труднощі сприйняття, яка обумовлена психологічним аспектом.

Субтитри з'являються на екрані лише на кілька секунд, впродовж яких глядач повинен їх прочитати та зрозуміти, тому вони повинні бути короткими. Якщо у діалогах наявні паузи, субтитри залишаються на екрані на кілька секунд довше, але таке буває рідко. Ще однією проблемою, що виникає при субтитруванні, є потреба виставляти часові мітки, що забирає дуже багато часу.

Цікавим є дослідження Ф. Карамітоглу (F. Каramitroglou) щодо швидкості читання субтитрів середньостатистичним глядачем (під «середньостатистичним глядачем» автор має на увазі представників верхнього сегменту середнього соціоосвітнього класу віком 14-65 років). За його підрахунками, читання тексту середньої складності відбувається зі швидкістю 150-180 слів за хвилину, що становить 2,5-3 слова за секунду [8, с. 82].

В результаті аналізу перекладу документальних фрільмів «Пластиковий океан» та «Земляни», било виявлено наступні особливості.

Назва фрільму «Пластиковий океан» була перекладена еквівалентно та адекватно. Можливо, можна б було підібрати більш вдалу назву, але ця назва, на відміну від нашого першого прикладу, говорить сама за себе і навіть гіперболізуе. Чуючи таку назву, глядачі уявляють собі пластиковий острів посеред океану. Але на справді все не так масштабно виглядає, однак є навіть більш небезпечно.

Перекладачем було виконане основне завдання - передати мету кінофрільму до аудиторії. Як i в нашому першому прикладі, переклад цього фольму був дуже якісним. Перекладацькі трансформації використовувалися доречно і не ускладнювали розуміння викладеного матеріалу.

Порівнюючи оригінал фрільму 3 перекладом, можна визначити, що переклад іноді запізнюється. Через те, що все відбувається наче в звичайному фільмі, тобто актори постійно змінюють своє положення, емоції та рухаються під час свого мовлення, реагуючи на певні умови, сам фрільм іноді нелегко дивитися. Але це більше стосується проблеми того, чому оригіналу і мови перекладу дуже відрізняються. Саме тому і виникають такі розбіжності.
В щілому переклад $є$ досить якісним. Переклад дуже добре передає інтенцію і головну мету всього фрільму.

Продивившись фрільм «Земляни» англійською, українською та російською, можна визначити, що переклад цілком виконав усі задачі та якомога точніше передав сенс 3 мови оригіналу. Під час перекладу було використано численну кількість перекладацьких трансформацій, як генералізація, конкретизація, описовий переклад, граматична трансформащії і т.д.

Неправильно підібрана трансформація негативно вплине на процес сприйняття фільму у перекладі. Переклад фрільму - дуже складний процес, під час якого увага приділяеться не тільки тексту, але й аудіовізуальним засобам.

Тому, якщо невлучно використати описовий переклад, це може затягнути час і будуть вже показані інші предмети, а не ті, про які йшлось в оригіналі.

Проаналізувавши переклад цього фільму, можна визначити недоліки по відношенню до тексту оригіналу. По-перше, в оригінальному звучанні, цей фрільм охоплюе багато культурних та чисто американських особливостей, тому для представників інших країн, особливо під час перекладу цієї кінострічки, дуже важко з першого разу визначити і зрозуміти як все відбувається.

Це все пояснюеться дуже просто. Наші культури: американська та українська - не є однаковими, або навіть схожими. Наші культури знаходяться далеко одна від одної. В нас е спільне розуміння певних явищ, але не всіх. Повторно беручи до уваги приклади 3 безпритульними тваринами. В Америці їх просто немає, адже як тільки собака опиняеться на вулиці без хазяїна, ïi одразу забирають до притулку. Проте розкривання цієї теми є досить важливою, адже таким чином ми розуміємо причину цих явищ. I доходячи до початку зародження проблеми, ми розуміємо, що саме люди повинні в багатьох з них.

Явища, про який говориться в фрільмі дуже швидко знаходяться правильний відповідник в українській мові. Особливо метод перекладащьких трансформацій, що можна використати для того чи іншого перекладу.

Раніше нами було визначено, щось не багато способів перекладу документальних фрільмів, і в кожному з них є свої недоліки. Приклад був зроблений за допомогою запису мовлення перекладача або актора. Проаналізувавши різні методи перекладу, можна визначити, що цей переклад був зроблений максимально правильно.

Більшість матеріалу було перекладено саме за допомогою еквівалентного перекладу. Еквівалентний переклад - переклад, що відповідає оригіналу на всіх релевантних рівнях і забезпечуе рішення тих же інформаційно-комунікативних завдань, на які був нащілений текст оригіналу.

Еквівалентів в проаналізованих прикладах було найбільше - всього 27,3\%: a warm-bloodedтеплокровні, a cold-blooded - холоднокровні

Конкретизацію було знайдено в 13,4\% проаналізованих прикладах: to serve mankind - експлуатуються людьми, find a new home againзнайти нового господаря, overcrowded conditions - в переповнених будках.

Модулящія зустрічалась в $12,4 \%$ проаналізованих прикладах: hazard of street life - небез- 
пек вуличного життя, emasculates the ownerкаструе господаря, administered by an injection - шляхом ін'єкції.

Опущення було використано в $12,4 \%$ проаналізованих прикладах: many nonhuman animals understand the world - багато тварин розуміють світ, remote from universal nature - віддалена від природи, ordinary human beings звичайні люди.

9,2\% прикладів були перекладені за допомогою граматичної заміни: to be considered earthling - вважаємося землянами, tends to dominate - прагнуть домінувати, the desire for foodжага бути ситим.

Додавання було використано в 7,7\% прикладів: are due from us - ми винні тваринам, morally ought to treat - повинні ставитись 3 погляду моралі, surveys the creatures - сприймає інші істоти.

Генералізація була застосована в 5,0\% прикладів: nonhuman animals - інші тварин, to dominate the Earth - домінувати на планеті, among the members of the human family - ceред людей.

4,5\% прикладів містить синтаксичну перестановку: an attitude of bias - упередженим ставлення, against those of members of other species - за рахунок ущемлення інтересів інших видів, to recognize the moral imperative of respect - дотримуемося принципів моралі.

Антонімічним перекладом користувались у 4,2\% випадків: morally disrespectful treatment аморальне ставлення, treat the less powerful as if they were mere objects - відносяться до слабкіших наче вони - просто предмети, receiving no exercise - не даючи волі.

Основними проблемами при перекладі фрільмів становила саме інтеграція деяких явищ, не традиційних в культурі України. Також, важливим було дотримання часу, що не завжди вдавалось робити максимально точно, але це не викривляло перегляд фольму і розуміння матеріалу.

Обидва фрільми є документальними і вони несуть в собі багато точної та інформації про реальні події. Однак, обидва фрільми є емоційно забарвленими, що є основним методом зацікавлення аудиторії у тому, що треба діяти і щось змінювати у своїй діяльності.
Під час аналізу перекладацьких трансрормацій, найчастіше було використано еквівалентний переклад. Однак, всі види трансформацій дуже важливі, але для документального фільму такий спосіб перекладу, як антонімічний не дуже широко розповсюджений.

Висновки та перспективи подальших досліджень. В результаті роботи було визначено та узагальнено лінгвокультурні особливості мови англомовного документального кінотексту та досліджено специфріку його перекладу українською мовою. Було визначено, що кінотекст - це текст, який виражений за допомогою вербальних і невербальних знаків, що організовані відповідно до задуму автора за допомогою кінематоградічних кодів, що зафріксован на носії і призначений для відтворення на екрані i аудіовізуального сприйняття глядачами. Переклад кіносценаріїв відноситься до художнього перекладу та в той же час має свої унікальні особливості. Чисто документальним фрільмом вважається такий фрільм, що був відзнятий і переглянуто «з першого дублю». Якщо текст накладаеться вже після відзнятого матеріалу, багато дослідників вважають, що це вже не є документальним фрільмом. Документальні фрільми можуть перекладатись за допомогою субтитрування, одноголосого, двох- або багатоголосого озвучування. Також існуе і синхронний переклад, але він не є популярним методом на сьогоднішній день. Було розглянуто англомовні документальні фільми і визначено їх лінгвокультурні особливості. Навіть документальні фільми, що розглядають глобальні проблеми мають бути перекладені за допомогою перекладацьких трансформацій адаптованих до культури мови перекладу. Було проаналізовано два документальні фрільми: «Земляни» та «Пластиковий океан», охарактеризовано переклад, підкреслення складнощів під час перекладу фрільмів такого типу в зв’язку з залежністю від часового проміжку, який віддаеться на оригінальний текст.

3 часом кількість документальних фрільмів буде збільшуватись, в результаті чого і потреба у перекладі їх українською. Оскільки культури англомовних країн суттево відрізняються від України, питання про лінгвокультурні особливості перекладу документальних фрільмів буде і далі актуальним.

\section{Список літератури:}

1. Гайданка Д.В. Дискурс кіно в ракурсі новітніх парадигм: особливості й типологія. Науковий вісник Міжнародного гуманітарного університету. Серія : Філологія. 2015. № 16. С. 99-101.

2. Гридасова О.I. Кінодискурс як об'ект навчання кіно перекладу. Вісник Житолирського державного університету ілені Івана Франка. 2014. № 2. С. 102-107.

3. Гудманян А.Г., Плетенецька Ю.М. До проблем кіноперекладу, як виду художнього перекладу Наукові записки Національного університету “Острозька академія”. Сер. : Філологічна. 2012. № 25. C. $28-30$.

4. Крисанова Т. Основні підходи до розуміння поняття “кінодискурс". Науковий вісник Східноєвропейського національного університету ілені Лесі Украӥнки. Філологічні науки. Мовознавство. 2014. № 4. С. $98-102$.

5. Лукьянова Т.Г. Лексичні аспекти перекладу субтитрів: на матеріалі англомовних художніх фрільмів. Нова фоілологія. 2012. № 50. С. 170-173.

6. Мельник М.Є. Кінотекст як особливий вид дискурсу. Сучасні дослідження з інозелної ббілологї̈. 2014 . № 12. C. $123-127$.

7. Anderman G., Rogers M. Translation Today Trends and Perspectives Multilingual Matters, 2003. 248 p.

8. Karamitroglou F. Towards A Methodology for the Investigation of Norms in Audiovisual Translation: The Choice between Subtitling and Revoicing in Greece. Amsterdam (Approaches to Translation Studies 15). Brill Rodopi, 2000. 312 p. 


\section{References:}

1. Haidanka D.V. (2015) Dyskurs kino v rakursi novitnikh paradyhm: osoblyvosti y typolohiia [Discourse of cinema in the perspective of the latest paradigms: features and typology]. Naukovyi visnyk Mizhnarodnoho humanitarnoho universytetu. Seriia: Filolohiia, no. 16, pp. 99-101. (in Ukrainian)

2. Hrydasova O.I. (2014) Kinodyskurs yak obiekt navchannia kino perekladu [Film discourse as an object of teaching film translation]. Visnyk Zhytomyrskoho derzhavnoho universytetu imeni Ivana Franka, no. 2, pp. $102-107$. (in Ukrainian)

3. Hudmanian A.H., Pletenetska Yu.M. (2012) Do problem kinoperekladu, yak vydu khudozhnoho perekladu [On the problems of film translation as a type of literary translation]. Naukovi zapysky Natsionalnoho universytetu "Ostrozka akademiia". Ser.: Filolohichna, no. 25, pp. 28-30. (in Ukrainian)

4. Krysanova T. (2014) Osnovni pidkhody do rozuminnia poniattia "kinodyskurs" [Basic approaches to understanding the concept of "film discourse"]. Naukovyi visnyk Skhidnoievropeiskoho natsionalnoho universytetu imeni Lesi Ukrainky. Filolohichni nauky. Movoznavstvo, no. 4, pp. 98-102. (in Ukrainian)

5. Lukianova T.H. (2012) Leksychni aspekty perekladu subtytriv: na materiali anhlomovnykh khudozhnikh filmiv [Lexical aspects of subtitle translation: on the material of English feature films]. Nova filolohiia. Zaporizhzhia, no. 50, pp. 170-173. (in Ukrainian)

6. Melnyk M.Ye. (2014) Kinotekst yak osoblyvyi vyd dyskursu [Kinotext as a special kind of discourse]. Suchasni doslidzhennia z inozemnoi filolohii, no. 12, pp. 123-127. (in Ukrainian)

7. Anderman G., Rogers M. (2003) Translation Today Trends and Perspectives Multilingual Matters, 248 p.

8. Karamitroglou F. (2000) Towards A Methodology for the Investigation of Norms in Audiovisual Translation: The Choice between Subtitling and Revoicing in Greece. Amsterdam (Approaches to Translation Studies 15). Brill Rodopi, 312 p. 